\title{
Efficacy of a Phosphate-Charged Soil Material in Supplying Phosphate for Plant Growth in Soilless Root Media
}

\author{
Young-Mi Oh, ${ }^{1}$ Paul V. Nelson, ${ }^{1}$ Dean L. Hesterberg, ${ }^{2}$ and Carl E. Niedziela Jr. ${ }^{3}$ \\ ${ }^{1}$ Department of Horticultural Science, North Carolina State University, Raleigh, NC 27695-7609, USA \\ ${ }^{2}$ Department of Soil Science, North Carolina State University, Raleigh, NC 27695-7619, USA \\ ${ }^{3}$ Department of Biology, Elon University, Elon, NC 27244, USA \\ Correspondence should be addressed to Carl E. Niedziela Jr.; cniedziela@elon.edu
}

Received 22 January 2016; Accepted 16 March 2016

Academic Editor: Manuel Tejada

Copyright (C) 2016 Young-Mi Oh et al. This is an open access article distributed under the Creative Commons Attribution License, which permits unrestricted use, distribution, and reproduction in any medium, provided the original work is properly cited.

\begin{abstract}
A soil material high in crystalline Fe hydrous oxides and noncrystalline Al hydrous oxides collected from the Bw horizon of a Hemcross soil containing allophane from the state of Oregon was charged with phosphate-P at rates of $0,2.2$, and 6.5 mg. ${ }^{-1}$, added to a soilless root medium at $5 \%$ and $10 \%$ by volume, and evaluated for its potential to supply phosphate at a low, stable concentration during 14 weeks of tomato (Solanum esculentum L.) seedling growth. Incorporation of the soil material improved $\mathrm{pH}$ stability, whether it was charged with phosphate or not. Bulk solution phosphate-P concentrations in the range of 0.13 to $0.34 \mathrm{mg} \cdot \mathrm{dm}^{-3}$ were associated with $\mathrm{P}$ deficiency. The only treatment that sustained an adequate bulk solution concentration of phosphate-P above $0.34 \mathrm{mg} \cdot \mathrm{dm}^{-3}$ for the 14 weeks of testing contained $10 \%$ soil material charged with $6.5 \mathrm{mg} \cdot \mathrm{g}^{-1} \mathrm{P}$, but initial dissolved P concentrations were too high ( $>5 \mathrm{mg} \cdot \mathrm{g}^{-1}$ phosphate-P) from the standpoint of phosphate leaching. The treatment amended with $10 \%$ soil material charged with $2.2 \mathrm{mg} \cdot \mathrm{g}^{-1} \mathrm{P}$ maintained phosphate-P within an acceptable range of 0.4 to $2.3 \mathrm{mg} \cdot \mathrm{dm}^{-3}$ for $48 \mathrm{~d}$ in a medium receiving no postplant phosphate fertilization.
\end{abstract}

\section{Introduction}

Containerized soilless media have low phosphate sorption capacities [1] and are subject to extensive leaching of applied nutrients due to high hydraulic conductivity. To assure adequate phosphate for plant growth, phosphate is typically applied multiple times at high concentrations, which leads to environmental problems [2,3]. Fertilizer solution phosphate-P concentrations of $14-44 \mathrm{mg} \cdot \mathrm{dm}^{-3}$ are common, which leads to bulk solution concentrations $\geq 15 \mathrm{mg} \cdot \mathrm{dm}^{-3}$ [4]. However, equilibrium bulk solution concentrations as low as $0.18 \mathrm{mg} \cdot \mathrm{dm}^{-3}$ phosphate-P for field grown chrysanthemums [5] and $0.2 \mathrm{mg} \cdot \mathrm{dm}^{-3}$ phosphate-P for most plant species have been reported to be adequate when provided constantly to plant roots at the rate of plant uptake [6].

Efforts to alleviate phosphate leaching in soilless root media have been directed toward establishment of a phosphate reserve that provides a low, sustained equilibrium (dissolved) concentration. Studies have included incubation with superphosphate [7] and amendment with anion exchange resins [8]. These treatments, however, were timeconsuming and expensive or failed to reduce phosphate leaching. As an alternative, phosphate-charged alumina (P$\mathrm{Al}_{2} \mathrm{O}_{3}$ ) was tested as an amendment in an experimental sand culture system [9]. Combining $\mathrm{P}-\mathrm{Al}_{2} \mathrm{O}_{3}$ with sand successfully maintained constant and steady phosphate concentrations for plant growth [9-12]. The phosphate-charged alumina amendment in a 70 peat moss: 30 perlite medium (by volume) effectively retained and slowly released phosphate during Chrysanthemum growth [13]. But alumina is an expensive media amendment in terms of crop production cost for the greenhouse industry. Phosphate-charged calcined arcillite and attapulgite clays added to a 70 peat moss: 30 perlite medium provided a less expensive source of phosphate that fully met the needs of a Chrysanthemum crop [13]. However, the rate of phosphate charging caused the initial phosphate equilibrium concentrations to be undesirably high in order to insure a sufficient concentration at the end of the crop. This system promoted phosphate leaching. 
Metal oxides and noncrystalline aluminosilicates like allophane have a high specific surface area and surface metal hydroxyl groups ( $>\mathrm{Fe}-\mathrm{OH}$ or $>\mathrm{Al}-\mathrm{OH}$ ) that adsorb oxyanions and metal cations as inner-sphere surface complexes, with a degree of covalent bonding that makes the ions less exchangeable $[14,15]$. The high phosphate adsorption capacity of these minerals could potentially be advantageous for reducing phosphate leaching and increasing efficiency of phosphate uptake in soilless root media.

In our previous studies to evaluate synthesized minerals for their phosphate adsorption capacities [16] and desorption characteristics [17], allophane (noncrystalline $\mathrm{Si}_{3} \mathrm{Al}_{4} \mathrm{O}_{12} \cdot n \mathrm{H}_{2} \mathrm{O}$ ) showed the most favorable potential among the four minerals tested (allophane, alumina $\left(\mathrm{Al}_{2} \mathrm{O}_{3}\right)$, goethite $(\alpha-\mathrm{FeOOH})$, and hematite $\left.\left(\alpha-\mathrm{Fe}_{2} \mathrm{O}_{3}\right)\right)$. Allophane had the highest phosphate adsorption capacity and released the largest quantity of phosphate. Alumina, goethite, and hematite had lower phosphate adsorption capacities and required a greater quantity of these minerals to be mixed with soilless media to supply sufficient phosphate for plant growth. Since synthesis of minerals requires high energy, using a natural soil material high in allophane or metal oxides would be more economically feasible in terms of production cost for the industry.

The objective of this study was to determine if phosphate could be supplied at an adequate, low, relatively constant concentration during 14 weeks of tomato seedling growth when a phosphate-charged natural soil material high in metal oxides and allophanic aluminosilicates was incorporated into a soilless root medium.

\section{Materials and Methods}

2.1. Characterization of Soil Properties. A soil material was collected from the Bw horizon of a Hemcross soil (medial, ferrihydritic, mesic Alic Hapludands) in the state of Oregon. This soil material was selected because it was of young volcanic origin, typically high in allophane and $\mathrm{Fe}$ and $\mathrm{Al}$ oxides. The soil material was stored at $4^{\circ} \mathrm{C}$ prior to testing to maintain field moisture and minimize any alteration of surface chemical properties by air-drying [18]. The sample was passed through a $2 \mathrm{~mm}$ sieve prior to measurement of soil properties. Soil moisture content was determined by ovendrying a subsample at $105^{\circ} \mathrm{C}$ to constant weight. Soil pH was measured on a 1 soil : 1 water $(w / v)$ sample [19]. Organic carbon content was measured by Walkley-Black method [20]. The content of $\mathrm{Al}, \mathrm{Si}$, and $\mathrm{Fe}$ in the soil material was measured by ammonium-oxalate extraction, pyrophosphate extraction, and dithionite-citrate extraction methods [21, 22]. Plantavailable $\mathrm{P}$ was measured by extraction with buffered alkaline solution [23].

2.2. Characterization of Phosphate Adsorption. A stock suspension of soil material was prepared in a $10 \mathrm{mM} \mathrm{KCl}$ background solution for use in developing phosphate adsorption isotherms. Potassium chloride saturation was used to avoid precipitation of phosphate with divalent cations such as $\mathrm{Ca}^{2+}$ that would interfere with adsorption measurements.
The stock suspension was prepared as follows: Six $250 \mathrm{~mL}$ centrifuge bottles, each containing $5.88 \mathrm{~g}$ of sieved, fieldmoist soil material (equal to $4.5 \mathrm{~g}$ dry solids) and $219.12 \mathrm{~mL}$ of deionized water (1 solid:50 suspension), were shaken for $24 \mathrm{~h}$. Then, $\mathrm{KCl}$ salt was weighed into the suspensions to give a $1 \mathrm{M}$ concentration, and the suspensions were shaken for 2 additional hours. The suspensions were centrifuged at 21,500 RCF (Relative Centrifugal Force) for $20 \mathrm{~min}$ after which the supernatant solutions were discarded. The soil samples were washed two more times by shaking with $1 \mathrm{M}$ $\mathrm{KCl}$ solution for $2 \mathrm{~h}$. They were then washed four times with $10 \mathrm{mM} \mathrm{KC1}$ solution to bring the background electrolyte to this concentration. After the final centrifugation, the six soil samples were rinsed into one bottle using a minimal amount of $10 \mathrm{mM} \mathrm{KC1}$ solution. The solids concentration of the final suspension was $0.052 \mathrm{~g} \cdot \mathrm{g}^{-1}$ as determined by oven-drying subsamples at $105^{\circ} \mathrm{C}$ to constant weight.

To characterize the adsorption envelope as shown in Figure 1(a) (plot of adsorbed phosphate- $\mathrm{P}$ versus $\mathrm{pH}$ for a given level of added phosphate [24]), six concentrations of $\mathrm{KH}_{2} \mathrm{PO}_{4}$ solution were formulated in a $10 \mathrm{mM} \mathrm{KC1}$ background solution, each at several $\mathrm{pH}$ levels varying from 4.0 to 9.0. While vigorously mixing, $1.54 \mathrm{~g}$ of the stock suspension (equal to $0.08 \mathrm{~g}$ dry solids) was weighed into each of a series of $50 \mathrm{~mL}$ centrifuge tubes, and $38.46 \mathrm{~g}$ of $\mathrm{KH}_{2} \mathrm{PO}_{4}$ solution was added to obtain a $40.00 \mathrm{~g}$ suspension sample containing $2 \mathrm{~g}$ dry solids per $\mathrm{kg}$ of suspension. The centrifuge tubes containing the sample suspensions were tightly capped and equilibrated by shaking for $48 \mathrm{~h}$ at 1.9 cycles per second in a water bath at $24^{\circ} \mathrm{C}$. The equilibrated samples were centrifuged at 20,210 RCF for $10 \mathrm{~min}$ and the supernatant solutions were collected. The $\mathrm{pH}$ level was measured on unfiltered subsamples of each of the supernatant solutions, and the remaining solution was vacuum-filtered through a $0.2 \mu \mathrm{m}$ polycarbonate membrane filter. Using the Murphy-Riley method [25], phosphate-P was measured in the filtered supernatant solutions and in the original series of $\mathrm{KH}_{2} \mathrm{PO}_{4}$ solutions added to each centrifuge tube. The amount of adsorbed phosphate-P was calculated as the difference between added phosphate-P and equilibrium dissolved phosphate- $\mathrm{P}$ (i.e., loss from solution). An adsorption isotherm at $\mathrm{pH} 6.0$ was constructed using best-fit statistical curves to interpolate between data points on the phosphate adsorption envelopes and to determine the maximum adsorption capacity of the soil material.

2.3. Greenhouse Experiments. To evaluate the soil material for supplying phosphate for plant growth as a preplant source, the soil material was charged with phosphate at three concentrations based on the adsorption isotherm (Figure 1(b)). The first concentration was selected from the upper end of the curve and contained an adsorbed phosphate-P concentration of $6.5 \mathrm{mg} \cdot \mathrm{g}^{-1}$ soil material with dissolved phosphate-P concentration of $400 \mathrm{mg} \cdot \mathrm{dm}^{-3}$. The second concentration contained an adsorbed phosphate-P concentration of $2.2 \mathrm{mg} \cdot \mathrm{g}^{-1}$ soil material with dissolved phosphate-P concentration of $50 \mathrm{mg} \cdot \mathrm{dm}^{-3}$. The third concentration was $0 \mathrm{mg}$ of adsorbed phosphate-P and was prepared in a similar manner to 


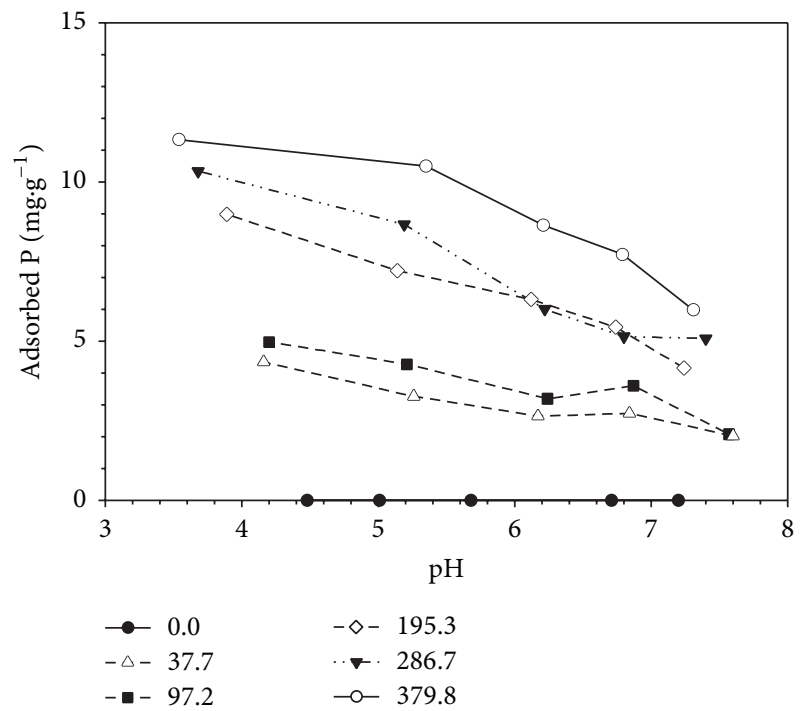

(a)

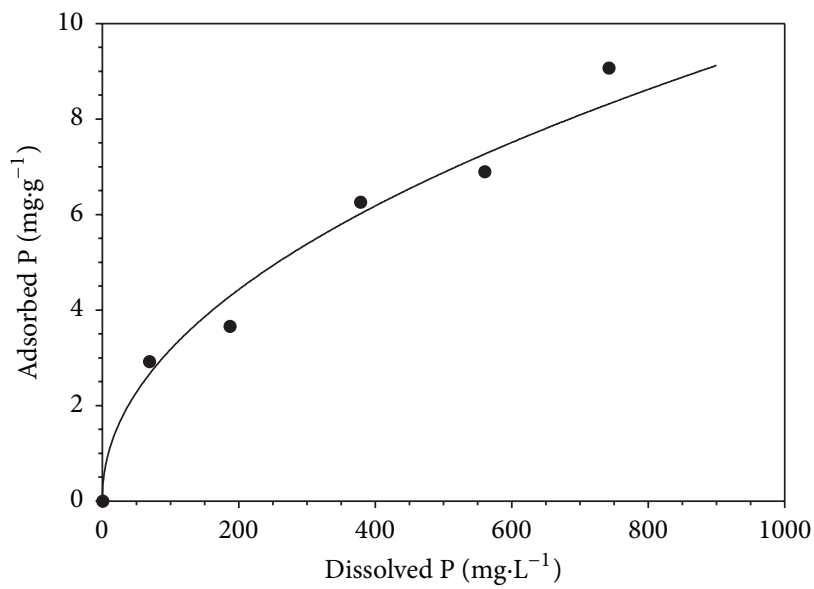

(b)

Figure 1: (a) Phosphate adsorption envelope at five $\mathrm{pH}$ levels of the soil material for various concentrations of added phosphate-P (10 $\mathrm{mM} \mathrm{KCl}$ background solution, $24^{\circ} \mathrm{C}$ ). Legend indicates the milligrams of phosphate-P added per gram of soil material. Lines connecting data points were included to aid in visualizing trends in the data. (b) Phosphate adsorption isotherm of soil at pH 6.0 with a van Bemmelen-Freundlich model fit.

the two previous rates. Phosphate charging was accomplished as follows. The field-moist soil material was passed through a $2 \mathrm{~mm}$ sieve and 2,614 $\mathrm{g}$ of soil material (equal to 2,000 $\mathrm{g}$ of solids) was weighed into a $12 \mathrm{~L}$ plastic bucket. To yield a 1 solid: 5 suspension ratio, 7,386 $\mathrm{mL}$ of deionized water was added to the soil material to obtain a $10 \mathrm{~L}$ suspension. The soil suspension was mixed with a stirrer for $2 \mathrm{~h}$; then $\mathrm{KCl}$ salt was added to the suspension to give $1 \mathrm{M}$ concentration and the suspension was stirred for an additional $2 \mathrm{~h}$. The suspension was then allowed to flocculate and settle before siphoning off the supernatant solution. The suspension was washed one more time with $1 \mathrm{M} \mathrm{KCl}$ solution and then four times with $10 \mathrm{mM} \mathrm{KC1}$ solution. After the last wash, $\mathrm{KH}_{2} \mathrm{PO}_{4}$ solution prepared to yield the desired adsorption was added to the soil material and $\mathrm{KOH}$ or $\mathrm{HCl}$ was added during $48 \mathrm{~h}$ of equilibration to obtain the final solution $\mathrm{pH}$ of $6.0 \pm 0.1$. After equilibration, the supernatant solution was siphoned off and collected for analysis to determine the amount of phosphate-P adsorbed on the soil material. The soil material was washed again with $10 \mathrm{mM} \mathrm{KCl}$ solution and then with deionized water by stirring for $1 \mathrm{~h}$ to remove excess phosphate in the solution before centrifugation at 21,500 RCF for $20 \mathrm{~min}$. The phosphate-charged soil material was then freeze-dried and ground through a $250 \mu \mathrm{m}$ sieve using a ball mill.

There were seven treatments in the greenhouse experiment including a control. The base soilless root medium consisted of 3 sphagnum peat moss (St-Raphael Peat Moss Ltd., Haut-Lameque, NB, Canada) : 1 perlite (Carolina Perlite Company Inc., Gold Hill, NC) by volume amended with 6 and $0.45 \mathrm{~g} \cdot \mathrm{dm}^{-3}$ of dolomitic limestone and Micromax (The Scotts Co., Marysville, $\mathrm{OH}$ ) micronutrient mix, respectively. No soil material was added to the root medium for the control treatment. In two treatments, uncharged soil material $\left(0 \mathrm{mg} \cdot \mathrm{g}^{-1} \mathrm{P}\right)$ was incorporated into the base medium at $5 \%$ and $10 \%$ of the final volume (designated as 0 P-5\% and 0 P-10\%, resp.). These treatments served to show the influence of the soil material without the effect of presorbed phosphate. The remaining four treatments were a factorial of two phosphate-P charging concentrations $\left(2.2\right.$ and $6.5 \mathrm{mg} \cdot \mathrm{g}^{-1}$ $\mathrm{P})$ and two incorporation rates of the charged soil material into the root medium (5\% and 10\%). These four treatments of $5 \%$ soil material charged with $2.2 \mathrm{mg}^{-1} \mathrm{P}, 10 \%$ charged with $2.2 \mathrm{mg} \cdot \mathrm{g}^{-1} \mathrm{P}, 5 \%$ charged with $6.5 \mathrm{mg} \cdot \mathrm{g}^{-1} \mathrm{P}$, and $10 \%$ charged with $6.5 \mathrm{mg} \cdot \mathrm{g}^{-1} \mathrm{P}$ were designated $2.2 \mathrm{P}-5 \%, 2.2 \mathrm{P}-$ $10 \%, 6.5$ P-5\%, and 6.5 P-10\%, respectively. The incorporation percentages equated to 40 and $80 \mathrm{~g}$ of the charged soil in $13.6-\mathrm{cm}(1.0 \mathrm{~L})$ standard plastic pots at 5 and $10 \%$ of the final volume, respectively. The former three treatments (control, 0 P-5\%, and 0 P-10\%) were fertilized with an $\mathrm{N}-\mathrm{P}-\mathrm{K}$ solution at each irrigation whereas the latter four treatments received an N-K fertilizer. Three successive crops were grown over a combined period of 14 weeks in the same pots containing the same media to determine the longevity of phosphate supply from the phosphate-charged soil material. In crops 1 and 2, a fertilizer containing $100 \mathrm{mg} \cdot \mathrm{dm}^{-3} \mathrm{~N}$ (2 $\mathrm{NH}_{4}{ }^{+}-\mathrm{N}: 3 \mathrm{NO}_{3}{ }^{-}-\mathrm{N}$ ) was applied as an N-P-K fertilizer consisting of $0.7 \mathrm{mM} \mathrm{NH}_{4} \mathrm{H}_{2} \mathrm{PO}_{4}, 2.1 \mathrm{mM} \mathrm{KNO}_{3}$, and $2.1 \mathrm{mM}$ $\mathrm{NH}_{4} \mathrm{NO}_{3}$ and with an N-K fertilizer consisting of $0.35 \mathrm{mM}$ $\left(\mathrm{NH}_{4}\right)_{2} \mathrm{SO}_{4}, 2.1 \mathrm{mM} \mathrm{KNO}_{3}$, and $2.1 \mathrm{mM} \mathrm{NH}_{4} \mathrm{NO}_{3}$. In crop 3 , these fertilizer formulations were increased by $50 \%$. In addition to the previously described lime and micronutrient amendments contained in the base soilless root medium, those treatments that received the N-P-K fertilizer (control, 0 $\mathrm{P}-5 \%$, and $0 \mathrm{P}-10 \%$ ) were amended with $0.9 \mathrm{~g} \cdot \mathrm{dm}^{-3}$ of gypsum 
to compensate for lack of $\mathrm{SO}_{4}{ }^{2-}$ that was contained in the $\mathrm{N}$ $\mathrm{K}$ fertilizer formulation.

Tomato seeds (“Colonial," Petoseed Co., Saticoy, CA) were germinated in the base soilless root medium. Twentyday-old tomato seedlings were then transplanted into $13.6 \mathrm{~cm}$ pots filled with $1.0 \mathrm{~L}$ of base soilless root medium amended as previously described for each treatment. Day and night temperatures were set at 25 and $20^{\circ} \mathrm{C}$, respectively. Fertilizer was applied at each watering (fertigation) with a $20 \%$ leaching fraction. Irrigation occurred when the surface of the medium in the pots started to dry.

Each week, bulk solutions were collected for $\mathrm{pH}$, phosphate-P, and $\mathrm{K}$ measurements by fertilizing the pots, allowing them to equilibrate for $1 \mathrm{~h}$, and then pouring $30 \mathrm{~mL}$ of water into each pot to displace a sample of bulk solution. The $\mathrm{pH}$ of bulk solutions was measured using a $\mathrm{pH}$ meter (Extech Instruments Corp., Waltham, MA). Phosphate-P was measured by the Murphy-Riley procedure [25] using a Perkin-Elmer Lambda 3 UV/VIS spectrophotometer (Perkin-Elmer, Norwalk, CT), and K was determined using the Perkin-Elmer 373 atomic absorption spectrophotometer (Perkin-Elmer, Norwalk, CT).

Plant height was measured weekly. Total above-ground shoots of plants were harvested to measure fresh weight and dry weight when the first cluster started to bloom. Harvested shoots were washed in $0.5 \mathrm{~N} \mathrm{HCl}$ solution for $1 \mathrm{~min}$ and rinsed with deionized water before drying at $70^{\circ} \mathrm{C}$ for tissue analysis. Dried tissue was ground in a stainless steel Wiley mill (Thomas Scientific, Philadelphia) to pass through a $1 \mathrm{~mm}$ screen (20 mesh). Nitrogen content in the tissue was analyzed using the Perkin-Elmer PE $2400 \mathrm{CHN}$ elemental analyzer (Perkin-Elmer, Norwalk, CT). Tissue used for $\mathrm{P}$ and $\mathrm{K}$ analyses was dry-ashed at $500^{\circ} \mathrm{C}$, dehydrated in $3 \mathrm{~N} \mathrm{HC1}$, and dissolved in $0.5 \mathrm{~N} \mathrm{HC1}$. Phosphorus and $\mathrm{K}$ were measured using an inductively couple plasma emission spectrometer, the Perkin-Elmer Plasma 2000 system (PerkinElmer, Norwalk, CT).

After plant shoots were removed from the first crop and later from the second crop, 20-day-old seedlings for the next crop were transplanted into the same pots and root medium used for the previous crop without removal of roots from the previous crop and with minimal disturbance of the root medium. The same cultural practices and data collection were employed during each crop.

2.4. Experimental Design and Statistical Analysis. Treatments were arranged in a randomized complete block design with three blocks and three pots per experimental unit. The bulk solution data were analyzed separately by individual crops as a two-way factorial with seven treatments in each crop and six sampling dates in crop 1, five sampling dates in crop 2, and five sampling dates in crop 3. With three blocks in each crop, there were 126, 105, and 105 experimental units in crops 1, 2, and 3, respectively. The growth and tissue analysis data were analyzed as a two-way factorial with three crops and seven treatments with three blocks (63 experimental units). Data were subjected to analysis of variance using PROC ANOVA (SAS 9.4, SAS Inst., Cary, NC). Means were separated using a protected LSD test at the 0.05 level of significance.

\section{Results and Discussion}

3.1. Characterization of Soil Properties. The soil material used in this study was acidic with a $\mathrm{pH}$ of 5.1 , contained only $0.23 \%$ concentration of organic carbon as expected since it was sampled from a B horizon, and had a water content of $0.235 \mathrm{~g} \cdot \mathrm{g}^{-1}$ soil. The amount of $\mathrm{Al}$ extracted by ammonium-oxalate extraction $\left(\mathrm{Al}_{\mathrm{O}}\right)$, which dissolves $\mathrm{Al}$ in allophane, imogolite, organic-matter complexes, and noncrystalline hydrous $\mathrm{Al}$ oxides, was $0.79 \%(\mathrm{w} / \mathrm{w})$. In contrast, $1.48 \% \mathrm{Al}$ was extracted by a dithionite-citrate extraction $\left(\mathrm{Al}_{\mathrm{D}}\right)$, which represents $\mathrm{Al}$ in organic complexes, noncrystalline $\mathrm{Al}$ hydrous oxides, and Al-substituted Fe oxides. These results suggested that this soil material contained a low level of allophane. A low concentration of allophane in this soil material was further indicated by the low oxalate-extractable $\mathrm{Si}\left(\mathrm{Si}_{\mathrm{O}}\right)$ concentration of $0.07 \%$. The Fe extracted by ammonium-oxalate extraction $\left(\mathrm{Fe}_{\mathrm{O}}\right)$ represents $\mathrm{Fe}$ in organic complexes and noncrystalline Fe hydrous oxides, and Fe extracted by dithionite-citrate extraction $\left(\mathrm{Fe}_{\mathrm{D}}\right)$ represents $\mathrm{Fe}$ in organic complexes and both are found in noncrystalline and crystalline Fe hydrous oxides. Since $\mathrm{Fe}_{\mathrm{D}}(7.73 \%)$ was much higher than $\mathrm{Fe}_{\mathrm{O}}(0.46 \%)$, this soil material contained mainly crystalline Fe hydrous oxides even though the soil series was described as ferrihydritic. Therefore, we concluded that the main phosphate-adsorbing solids in this soil material were crystalline Fe hydrous oxides and noncrystalline Al hydrous oxides, suggesting that the soil sample was collected above the more allophonic-rich zone of the B horizon. However, no direct measurements of allophane were made. The soil material was found to contain almost no plant-available $\mathrm{P}, 0.001 \mathrm{mg}^{-1} \mathrm{P}$, by the buffered alkaline solution extraction method [23].

3.2. Phosphate Adsorption Characteristics. The phosphate adsorption envelope of the soil material for different concentrations of added $\mathrm{P}$ had typical patterns of decreased adsorption with increasing $\mathrm{pH}$ (Figure 1(a)). The adsorption isotherm indicated that the maximum phosphate- $\mathrm{P}$ adsorption capacity of the soil material approached $10 \mathrm{mg} \cdot \mathrm{g}^{-1} \mathrm{P}$ for a dissolved phosphate- $\mathrm{P}$ concentration of $900 \mathrm{mg} \cdot \mathrm{dm}^{-3}$ at $\mathrm{pH}$ 6.0 (Figure 1(b)), consistent with the adsorption envelopes. The phosphate adsorption capacity of this soil material was much lower than those of minerals synthesized and tested at this same $\mathrm{pH}$ by $\mathrm{Oh}$ et al. [16]. Adsorbed phosphate capacities for allophane, goethite, and alumina reported in the previous study were $>39,15.7$, and $14.8 \mathrm{mg} \cdot \mathrm{g}^{-1} \mathrm{P}$. However, oxide and allophanic minerals represent only a fraction of the total mass of the soil material, which also constitutes sand and silt particles of lower specific surface area. For example, the dithionite-citrate extractable $\mathrm{Fe}$ and $\mathrm{Al}$ concentrations of 7.73 and $1.48 \%$ are equivalent of $12.3 \% \mathrm{FeOOH}$ (goethite) and $3.23 \% \mathrm{AlOOH}$ (alumina), which would produce a soil phosphate adsorption capacity of only $2.4 \mathrm{mg} \cdot \mathrm{g}^{-1}$ soil. This calculation suggests that the soil contained considerable high-P adsorbing mineral such as allophane that was not necessarily extracted by oxalate and dithionite extractions.

3.3. Greenhouse Experiments: Uncharged Soil Material. Both the 0 P-5\% and 0 P-10\% treatments developed P deficiency 
TABLE 1: Tomato shoot height, fresh weight, and dry weight at the end of three successive seedling crops grown in root media amended with no soil material (control) and six soil material treatments combinations containing 5 or $10 \%$ soil material (v/v) charged with $0,2.2$, or 6.5 mg.g ${ }^{-1}$ phosphate- $\mathrm{P}^{\mathrm{y}}$.

\begin{tabular}{|c|c|c|c|c|c|c|c|c|c|}
\hline \multirow{2}{*}{ Treatment } & \multicolumn{3}{|c|}{ Ht. $(\mathrm{cm})$} & \multicolumn{3}{|c|}{ Fresh wt. (g) } & \multicolumn{3}{|c|}{ Dry wt. (g) } \\
\hline & Crop 1 & Crop 2 & Crop 3 & Crop 1 & Crop 2 & Crop 3 & Crop 1 & Crop 2 & Crop 3 \\
\hline Control & 41.7 & 42.9 & 47.3 & 72.6 & 89.7 & 101.9 & 9.9 & 10.1 & 9.8 \\
\hline 0 P-5\% soil & 43.4 & 43.2 & 47.3 & 78.1 & 88.7 & 98.2 & 10.2 & 10.2 & 9.7 \\
\hline 0 P-10\% soil & 29.3 & 42.3 & 47.8 & 24.1 & 90.1 & 97.8 & 2.4 & 9.9 & 9.9 \\
\hline 2.2 P-5\% soil & 47.4 & 38.7 & 17.9 & 95.3 & 55.2 & 11.3 & 12.7 & 6.2 & 1.4 \\
\hline 2.2 P-10\% soil & 48.4 & 44.8 & 33.6 & 103.1 & 95.7 & 48.1 & 13.4 & 10.9 & 6.1 \\
\hline 6.5 P-5\% soil & 48.7 & 43.7 & 42.1 & 98.0 & 89.7 & 73.5 & 12.9 & 10.4 & 8.8 \\
\hline 6.5 P-10\% soil & 48.6 & 45.1 & 47.4 & 101.9 & 98.0 & 106.3 & 13.3 & 11.1 & 11.3 \\
\hline $\mathrm{LSD}_{0.05}^{\mathrm{z}}$ & & 2.20 & & & 5.52 & & & 0.86 & \\
\hline
\end{tabular}

${ }^{\mathrm{y}}$ Crops 1, 2, and 3 were harvested at first cluster bloom (37, 27, and 36 days after transplanting 20-day-old seedlings, resp.).

${ }^{\mathrm{z}} \mathrm{LSD}$ values are for comparing soil material treatments within a given crop or crops within a given soil material treatment.

symptoms by $10 \mathrm{~d}$ into crop 1 , even though they received phosphate in the fertigation program equivalent to that in the $0 \mathrm{P}-0 \%$ control treatment which was free of $\mathrm{P}$ deficiency. These results indicate that phosphate in the added nutrient solutions was adsorbed by the soil material added in the $0 \mathrm{P}-$ $5 \%$ and 0 P- $10 \%$ treatments. Plants in the 0 P-5\% treatment recovered from the symptoms after two weeks of growth in crop 1 while 0 P- $10 \%$ plants did not recover during crop 1. Plants grown in crop 2 developed deficiency symptoms from a few days up to $10 \mathrm{~d}$. Symptoms were consistent with $\mathrm{P}$ deficiency, which included stunting, exceptionally deep green foliage, and purple pigmentation on the lower surface of leaves. The plants in the 0 P-5\% treatment completely regained size relative to control plants by the end of crop 1 , as seen in the growth measurements of height and fresh and dry weight (Table 1). The $0 \mathrm{P}-10 \%$ plants were much smaller than the control plants at the end of crop 1 . At the end of crops 2 and 3, plants in both $0 \mathrm{P}$ soil material treatments did not exhibit $\mathrm{P}$ deficiency symptoms or difference in size from control plants.

Bulk solution phosphate-P concentrations in the $0 \mathrm{P}-5 \%$ treatment ranged from 0.2 to $0.6 \mathrm{mg} \cdot \mathrm{dm}^{-3}$ in crop 1 , from 1.2 to $3.3 \mathrm{mg} \cdot \mathrm{dm}^{-3}$ in crop 2 , and from approximately 2.7 to $17.3 \mathrm{mg} \cdot \mathrm{dm}^{-3}$ in crop 3 (Table 2). All of these concentrations were lower than in the control treatment medium. Root medium phosphate-P concentrations were consistently lower in the $0 \mathrm{P}-10 \%$ compared to the $0 \mathrm{P}-5 \%$ treatments. These results were consistent with phosphate being sorbed by the soil material and that sorption was greater with the higher amount of soil material incorporated into the root medium, as would be expected from the adsorption isotherm in Figure 1(b). While depletion of applied phosphate was less at the end of the experiment, it still occurred. These effects can be seen likewise in the shoot P concentrations (Table 3). Tissue $\mathrm{P}$ was lower, compared to the control plants, at the end of the first two crops in plants in the $0 \mathrm{P}-5 \%$ treatment and during all three crops in the $0 \mathrm{P}-10 \%$ plants. These data point to the problem that could ensue if high phosphate fixation capacity soil material without supplemental phosphate was added to root medium. The soil material did not appear to have adverse effects on the crops other than $P$ deficiency since after the $\mathrm{P}$ deficiency dissipated, growth did not differ in the control versus the $0 \mathrm{P}-5 \%$ and $0 \mathrm{P}-10 \%$ treated plants.

3.4. Greenhouse Experiments: Charged Soil Material. Within each crop, tissue $\mathrm{P}$ concentrations related well to the quantity of phosphate provided in the form of phosphate-charged soil material (Table 3). Throughout the three crops, tissue P concentrations declined over time as phosphate was released from the soil material and dissolved concentrations were lower. Plant growth in crop 1, measured as height, fresh weight, and dry weight, in the $2.2 \mathrm{P}$ and $6.5 \mathrm{P}$ treatments exceeded growth of control plants (Table 1). Compared to the control plants, the final crop 1 shoot concentration of $\mathrm{P}$ was higher in all of these treatments except the 2.2 P-5\% treated plants (Table 3 ). However, that lower P concentration was concluded to be adequate because growth parameters exceeded those of the control. A positive relationship has been reported between $\mathrm{P}$ tissue concentration and growth of young plants, including tomato, up to $\mathrm{P}$ levels three or more times higher than the minimum adequate levels established for mature crops [26]. However, the greater levels of growth associated with higher-than-adequate phosphate concentrations were not deemed desirable for container grown plants due to etiolation within the constrained space required for commercial container production. Although the normal range of tomato tissue $\mathrm{P}$ has been reported to be 0.3 to $0.8 \%$ [27], it was not possible to determine adequacy of phosphate from our shoot $\mathrm{P}$ concentrations alone. Foliar tissue standards were developed for specific, relatively young leaves, whereas we analyzed the entire shoots that also contained stems and older leaves. Stems and older leaves are typically lower in $\mathrm{P}$ than younger leaves. Tissue $\mathrm{P}$ concentrations at the end of the crop in plants that exhibited $\mathrm{P}$ deficiency symptoms were $0.13 \%, 0.11 \%, 0.12 \%$, and $0.14 \%$ for plants in treatments 2.2 P-5\% in crop 2, $2.2 \mathrm{P}-5 \%$ in crop 3, $2.2 \mathrm{P}-10 \%$ in crop 3, and $6.5 \mathrm{P}-5 \%$ in crop 3, respectively (Table 3).

Two weeks after the start of crop 2, plants in $2.2 \mathrm{P}-5 \%$ treatment started to exhibit $\mathrm{P}$ deficiency symptoms. These 
TABLE 2: Phosphorus concentration in bulk solutions of root media amended with no soil material (control) and six soil material treatment combinations containing 5 or $10 \%$ soil material (v:v) charged with $0,2.2$, or $6.5 \mathrm{mg} \cdot \mathrm{g}^{-1}$ phosphate-P during three successive tomato seedling crops $^{\mathrm{x}}$.

\begin{tabular}{|c|c|c|c|c|c|c|c|c|c|c|c|c|c|c|c|c|}
\hline \multirow{3}{*}{ Trt } & \multicolumn{6}{|c|}{ Crop $1(\mathrm{DAT})^{\mathrm{y}}$} & \multicolumn{5}{|c|}{ Crop 2 (DAT) } & \multicolumn{5}{|c|}{ Crop 3 (DAT) } \\
\hline & 4 & 11 & 16 & 21 & 24 & 37 & 0 & 11 & 16 & 25 & 27 & 0 & 15 & 21 & 27 & 36 \\
\hline & \multicolumn{16}{|c|}{ Bulk solution $\mathrm{P}\left(\mathrm{mg} \cdot \mathrm{dm}^{-3}\right)$} \\
\hline Control & 8.85 & 6.19 & 13.72 & 4.39 & 5.87 & 18.66 & 16.79 & 13.53 & 13.39 & 8.83 & 17.48 & 15.97 & 22.05 & 21.85 & 29.71 & 33.42 \\
\hline 0 P-5\% & 0.39 & 0.57 & 0.46 & 0.34 & 0.21 & 0.53 & 1.18 & 2.25 & 3.29 & 1.43 & 1.86 & 2.71 & 4.36 & 5.48 & 7.68 & 17.34 \\
\hline 0 P-10\% & 0.33 & 0.34 & 0.33 & 0.30 & 0.25 & 0.18 & 0.14 & 0.47 & 0.41 & 0.49 & 0.57 & 0.67 & 1.01 & 1.19 & 2.28 & 7.58 \\
\hline $2.2 \mathrm{P}-5 \%$ & 2.40 & 1.90 & 0.97 & 0.51 & 0.33 & 0.20 & 0.23 & 0.34 & 0.23 & 0.27 & 0.19 & 0.30 & 0.16 & 0.15 & 0.16 & 0.13 \\
\hline 2.2 P-10\% & 2.29 & 1.77 & 1.28 & 0.75 & 0.51 & 0.28 & 0.38 & 0.49 & 0.32 & 0.32 & 0.23 & 0.37 & 0.19 & 0.18 & 0.20 & 0.21 \\
\hline 6.5 P-5\% & 43.30 & 29.18 & 20.06 & 5.98 & 4.08 & 0.78 & 1.02 & 2.26 & 1.34 & 0.46 & 0.35 & 0.69 & 0.43 & 0.21 & 0.17 & 0.23 \\
\hline 6.5 P-10\% & 58.00 & 41.24 & 30.65 & 15.69 & 10.47 & 2.89 & 5.02 & 8.73 & 4.81 & 1.66 & 1.08 & 3.64 & 1.43 & 0.81 & 0.54 & 0.45 \\
\hline $\operatorname{LSD}_{0.05}{ }^{\mathrm{z}}$ & \multicolumn{6}{|c|}{1.27} & & & 1.32 & & & & & 1.15 & & \\
\hline
\end{tabular}

${ }^{\mathrm{x}}$ Bold italic values within treatments were associated with symptoms of $\mathrm{P}$ deficiency when the sample was collected.

${ }^{\mathrm{y}}$ Days after transplanting of 20-day-old tomato seedlings.

${ }^{\mathrm{z}}$ LSD values are for comparing soil material treatments within a given crop or crops within a given soil material treatment.

TABLE 3: Nutrient concentrations in tomato shoots at the end of three successive seedling crops grown in root media amended with no soil material (control) and six soil material treatments combinations containing 5 or $10 \%$ soil material (v/v) charged with $0,2.2$, or $6.5 \mathrm{mg}^{-1} \mathrm{~g}^{-1}$ phosphate- $\mathrm{P}^{\mathrm{y}}$.

\begin{tabular}{|c|c|c|c|c|c|c|c|c|c|}
\hline \multirow{3}{*}{ Treatment } & \multicolumn{9}{|c|}{ Nutrient (\%) } \\
\hline & \multicolumn{3}{|c|}{$\mathrm{N}$} & \multicolumn{3}{|c|}{$\mathrm{P}$} & \multicolumn{3}{|c|}{$\mathrm{K}$} \\
\hline & Crop 1 & Crop 2 & Crop 3 & Crop 1 & Crop 2 & Crop 3 & Crop 1 & Crop 2 & Crop 3 \\
\hline Control & 2.29 & 3.30 & 4.77 & 0.31 & 0.52 & 0.90 & 2.38 & 3.23 & 4.09 \\
\hline 0 P-5\% soil & 2.39 & 3.27 & 4.73 & 0.22 & 0.47 & 0.88 & 3.34 & 3.29 & 4.17 \\
\hline 0 P-10\% soil & 3.90 & 4.88 & 4.45 & 0.26 & 0.38 & 0.68 & 4.80 & 4.86 & 4.12 \\
\hline 2.2 P-5\% soil & 2.25 & 4.52 & 3.97 & 0.24 & 0.13 & 0.11 & 3.34 & 4.50 & 3.42 \\
\hline 2.2 P-10\% soil & 2.19 & 4.99 & 3.62 & 0.38 & 0.19 & 0.12 & 3.50 & 4.95 & 3.78 \\
\hline 6.5 P-5\% soil & 2.09 & 4.22 & 3.64 & 0.70 & 0.30 & 0.14 & 3.32 & 4.15 & 4.02 \\
\hline 6.5 P-10\% soil & 1.89 & 5.00 & 4.16 & 0.82 & 0.63 & 0.34 & 3.44 & 4.94 & 4.37 \\
\hline $\mathrm{LSD}_{0.05}{ }^{\mathrm{z}}$ & & 0.37 & & & 0.05 & & & 0.35 & \\
\hline
\end{tabular}

${ }^{y_{C}}$ Crops 1, 2, and 3 were harvested at first cluster bloom (37, 27, and 36 days after transplanting 20-day-old seedlings, resp.).

${ }^{\mathrm{z}} \mathrm{LSD}$ values are for comparing soil material treatments within a given crop or crops within a given soil material treatment.

plants were smaller at the end of this crop than the control plants (Table 1). Plants grown in the $2.2 \mathrm{P}-10 \%, 6.5 \mathrm{P}-5 \%$, and 6.5 $\mathrm{P}-10 \%$ treatments did not differ in growth from the control plants except in the $2.2 \mathrm{P}-10 \%$ treatment where fresh weight was greater than the control plants and in the $6.5 \mathrm{P}-10 \%$ treatment where fresh weight and dry weight were greater than the control plants. In crop 3, P deficiency symptoms developed after two days in the $2.2 \mathrm{P}-10 \%$ treatment and at $20 \mathrm{~d}$ in the crop in the $6.5 \mathrm{P}-5 \%$ treatment. These plants finished smaller in height, fresh weight, and dry weight than the control plants. Treatment 6.5 P-10\% plants were the only plants that received adequate phosphate throughout the three crops. These plants ended similar in height and fresh weight but higher in dry weight than the control plants.

The minimum critical bulk solution phosphate-P concentration for tomato in peat moss-perlite medium can be estimated from data in Table 2. Average bulk solution phosphate$\mathrm{P}$ concentrations during the periods of $\mathrm{P}$ deficiency for the 0 P-10\%, 2.2 P-5\%, $2.2 \mathrm{P}-10 \%$, and $6.5 \mathrm{P}-5 \%$ treatments were $0.22,0.20,0.20$, and $0.20 \mathrm{mg} \cdot \mathrm{dm}^{-3}$, respectively. Bulk solution phosphate-P concentrations throughout these periods ranged from 0.13 to $0.34 \mathrm{mg} \cdot \mathrm{dm}^{-3}$, an indication that this range is in the deficient zone. Nishimoto et al. [5] placed the minimum critical concentration of $\mathrm{P}$ in bulk solution to attain 95\% of maximum growth of field grown Chrysanthemum at $0.18 \mathrm{mg} \cdot \mathrm{dm}^{-3}$. Their soil type was a Typic Eutrandept Kula which has a high phosphate fixation capacity. The soil was charged with superphosphate in accordance with its phosphate adsorption isotherm to achieve various initial bulk solution equilibrium concentrations. The higher required phosphate level in the soilless medium of our study may be due to the coarser texture with its lower unsaturated hydraulic conductivity and thus more tortuous water pathway for phosphate diffusion to roots.

Because phosphate-adsorbing minerals in soils serve as a reservoir for phosphate-P in solution, dissolved phosphate$\mathrm{P}$ concentrations in root media were mainly controlled by the phosphate concentration at which the soil material 


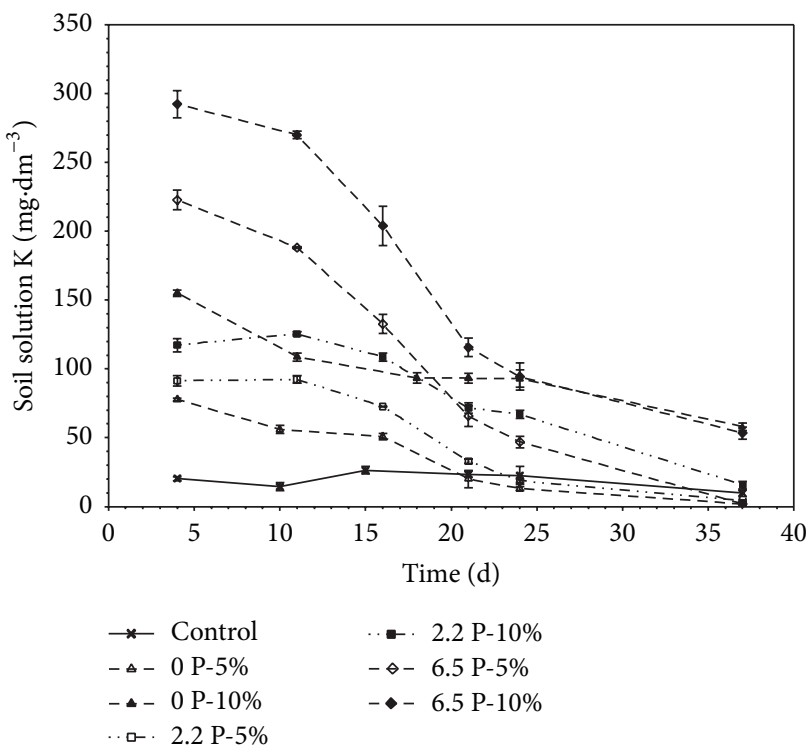

(a)

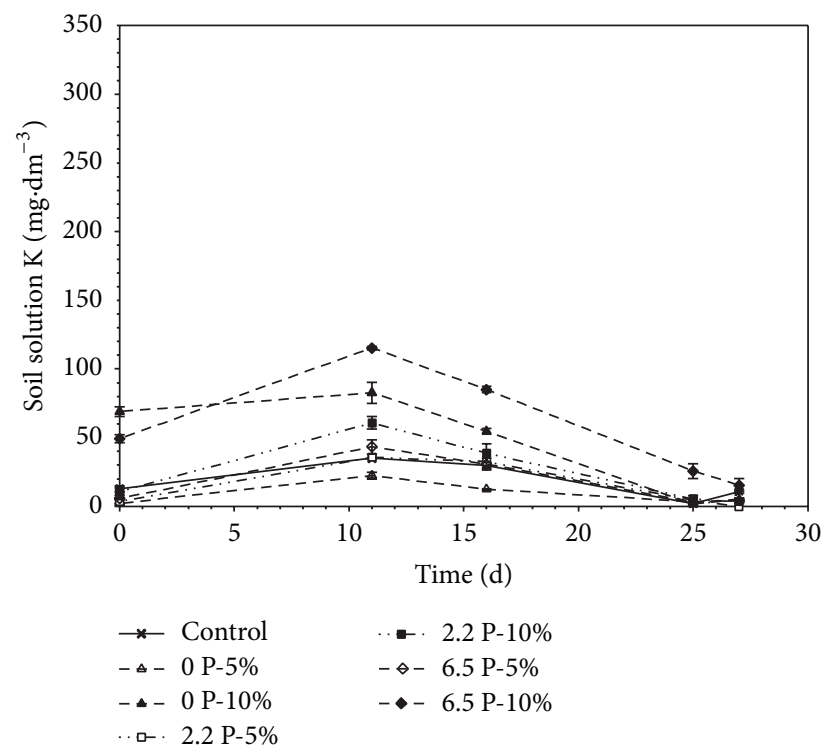

(b)

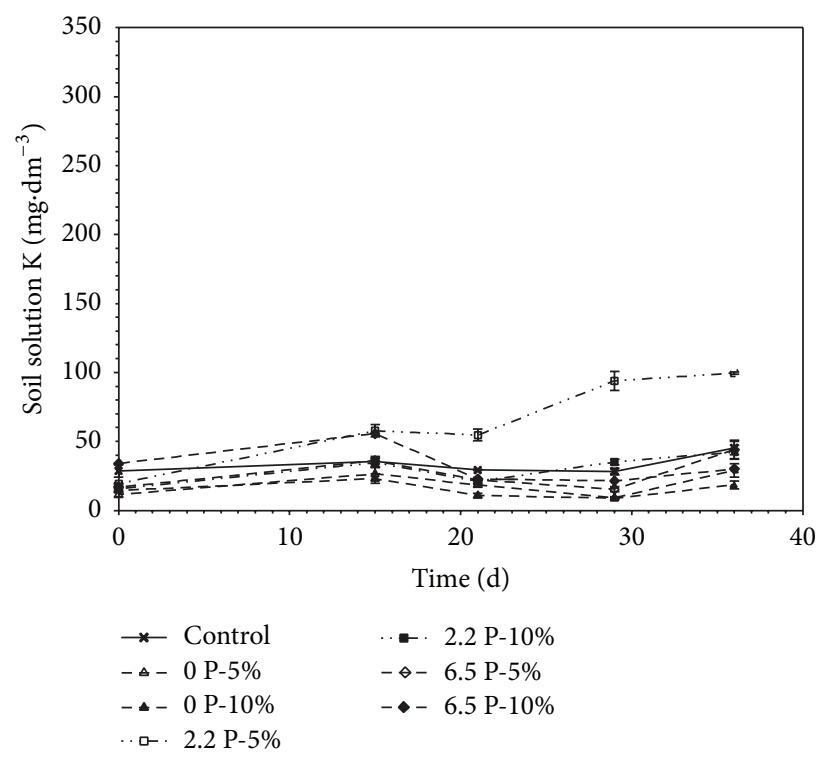

(c)

FIGURE 2: Potassium concentration in bulk solutions of root media amended with no soil material (control) and six soil material treatment combinations containing 5 or $10 \%$ soil material (v:v) charged with $0,2.2$, or $6.5 \mathrm{mg} \cdot \mathrm{g}^{-1}$ phosphate-P during the (a) first, (b) second, and (c) third of three successive tomato seedling crops. Bars indicate \pm SE $(n=3)$. Lines connecting data points were included to aid in visualizing trends in the data.

was charged. This was seen in the large difference in bulk solution phosphate-P concentrations between the pair of 2.2 $\mathrm{P}$ treatments and the pair of 6.5 $\mathrm{P}$ treatments and the relatively smaller differences within each pair of treatments (Table 2). The increased longevity of phosphate release was strongly under the control of both the quantity of phosphate-charged soil material added to the root medium and the phosphate concentration at which the soil material was charged.

Increased growth in some treatments with phosphatecharged soil material compared to the control plants may have been due in part to the increased supply of $\mathrm{K}$ from the phosphate-charged soil. The shoot concentrations of $\mathrm{K}$ were higher in all treatments compared to the control in crop 1 and higher in all treatments except 0 P-5\% in crop 2 (Table 3). There were no shoot $\mathrm{K}$ concentrations higher than in the control in crop 3. This same pattern is seen in root medium dissolved $\mathrm{K}$ concentration (Figure 2). All soil material treatments in the first crop resulted in higher root medium $\mathrm{K}$ concentrations than the concentration in the control. The curves for the second crop illustrate the contribution of $\mathrm{K}$ from soil material becoming depleted. Soil material contributed $\mathrm{K}$ whether it was charged with $\mathrm{KH}_{2} \mathrm{PO}_{4}$ 


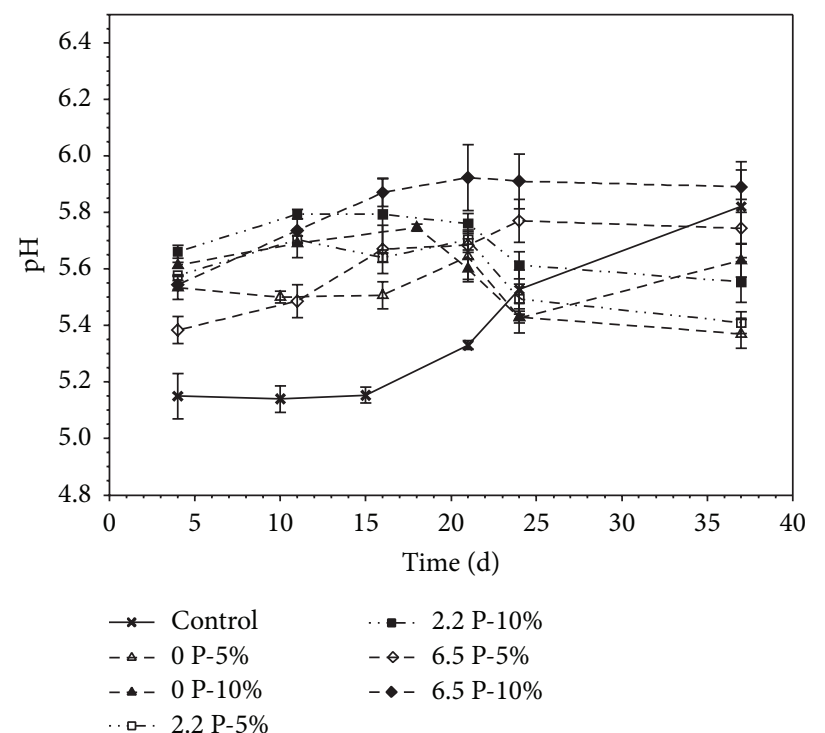

(a)

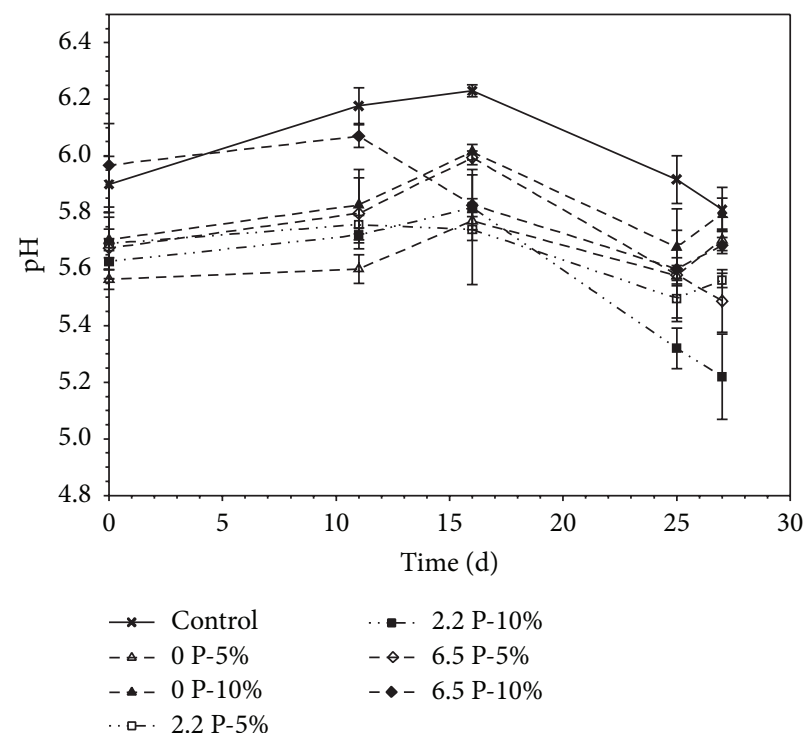

(b)

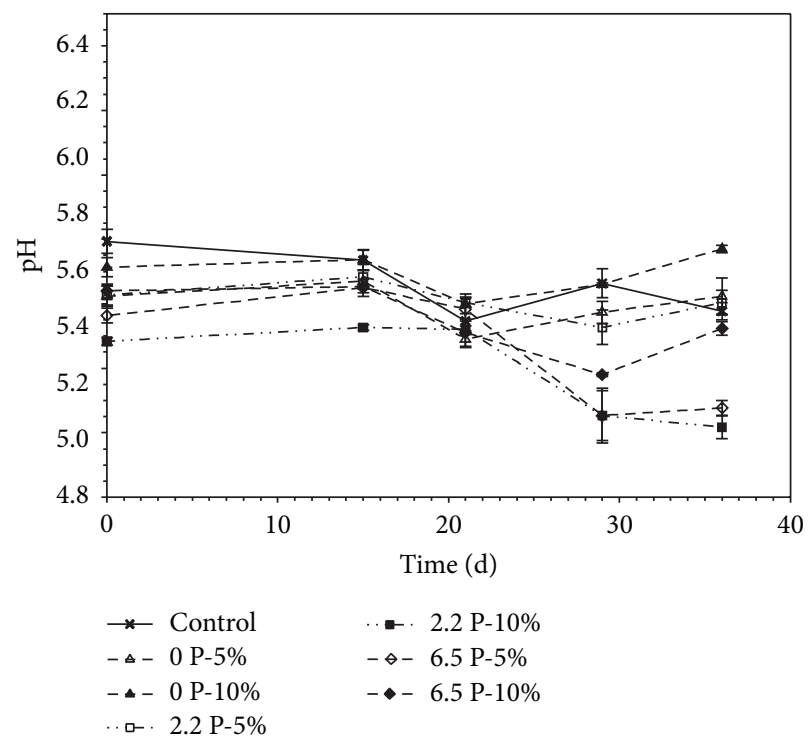

(c)

Figure 3: The $\mathrm{pH}$ of root media amended with no soil (control) and six soil treatment combinations containing 5 or $10 \%$ soil material (v: $\mathrm{v}$ ) charged with $0,2.2$, or $6.5 \mathrm{mg} \cdot \mathrm{g}^{-1}$ phosphate-P during the (a) first, (b) second, and (c) third of three successive tomato seedling crops. Bars indicate $\pm \operatorname{SE}(n=3)$. Lines connecting data points were included to aid in visualizing trends in the data.

or not. This can be attributed to K sorbed on the soil material during washing with $\mathrm{KCl}$ and in the case of soils charged with phosphate, from the additional equilibration with $\mathrm{KH}_{2} \mathrm{PO}_{4}$. However, the possible growth stimulatory effect of $\mathrm{K}$ would have been weak because no stimulation was recorded in half of the treatments where tissue levels of $\mathrm{K}$ were elevated.

Treatments with soil material (including $0 \mathrm{P}$ treatments) generally showed less fluctuation in root medium $\mathrm{pH}$ than the control during growth of the three crops, especially during crops 1 and 2 (Figure 3). Stabilization of root medium $\mathrm{pH}$ would be a valuable property for any phosphate-charged soil material intended for incorporation in soilless media for commercial crop production.

\section{Conclusions}

Adding soil material that has not been charged with phosphate to a soilless root medium receiving phosphate from a continuous postplant liquid fertilization program can result in $\mathrm{P}$ deficiency due to adsorption of added $\mathrm{P}$ by soil solids. Phosphate-charged soil material resulted in low, relatively stable bulk solution phosphate-P concentrations. Phosphate-P concentration was most heavily affected by the level of phosphate charging on the soil material while bulk solution phosphate-P longevity depended extensively on both the level of phosphate charging and the amount of charged soil material. These parameters could be varied to optimize 
the amount of charging and mass to mix with soilless media, given that the soil may deteriorate physical properties of the media such as hydraulic conductivity and aeration. In our study, the only treatment that sustained an adequate bulk solution concentration of phosphate-P for the 14 weeks of testing was $6.5 \mathrm{P}-10 \%$, but concentrations during crop 1 were too high from the standpoint of phosphate leaching. The objective of the study, to provide a low, adequate phosphate$\mathrm{P}$ concentration (above $0.34 \mathrm{mg} \cdot \mathrm{dm}^{-3}$ ), was best met in the $2.2 \mathrm{P}-10 \%$ treatment where bulk solution phosphate-P ranged from an initial concentration of $2.29 \mathrm{mg} \cdot \mathrm{dm}^{-3}$ to a concentration of $0.49 \mathrm{mg} \cdot \mathrm{dm}^{-3} 48 \mathrm{~d}$ later. Initially high phosphate$\mathrm{P}$ concentrations in bulk solution might be reduced by using a natural soil material with the higher phosphate sorption capacity of allophane and equilibrating it with a lower solution phosphate concentration. This would extend the length of time within a desirable bulk solution phosphate concentration and lower phosphate leaching.

\section{Disclosure}

The use of trade names in this publication does not imply endorsement by the North Carolina Agricultural Research Service of the products named nor criticism of similar ones not mentioned.

\section{Competing Interests}

The authors declare that they have no competing interests.

\section{Acknowledgments}

Appreciation is expressed to Sun Gro Horticulture, Bellevue, WA, and the North Carolina Agricultural Research Service (NCARS), Raleigh, NC, for support.

\section{References}

[1] D. J. Marconi and P. V. Nelson, "Leaching of applied phosphorus in container media," Scientia Horticulturae, vol. 22, no. 3, pp. 275-285, 1984.

[2] C. S. M. Ku and D. R. Hershey, "Growth response, nutrient leaching, and mass balance for potted poinsettia. II. Phosphorus," Journal of the American Society for Horticultural Science, vol. 122, no. 3, pp. 459-464, 1997.

[3] K. A. Williams and P. V. Nelson, "Low, controlled nutrient availability provided by organic waste materials for chrysanthemum," Journal of the American Society for Horticultural Science, vol. 117, no. 3, pp. 422-429, 1992.

[4] Southern Nursery Association, Best Management Practices: Guide for Producing Nursery Crops, Southern Nursery Association, Acworth, Ga, USA, 3rd edition, 2013.

[5] R. K. Nishimoto, R. L. Fox, and P. E. Parvin, "External and internal phosphate requirements of field grown chrysanthemums," HortScience, vol. 10, no. 3, pp. 279-280, 1975.

[6] R. S. Beckwith, "Sorbed phosphate at standard supernatant concentration as an estimate of the phosphate needs of soils," Australian Journal of Experimental Agriculture and Animal Husbandry, vol. 5, no. 16, pp. 52-58, 1965.
[7] T. H. Yeager and J. E. Barrett, "Phosphorus and sulfur leaching from an incubated superphosphate-amended soilless container medium," HortScience, vol. 20, no. 4, pp. 671-672, 1985.

[8] T. H. Yeager and J. E. Barrett, "Influence of an anion exchange resin on phosphorus and sulfur leaching from a soilless container medium," HortScience, vol. 21, no. 1, article 152, 1986.

[9] R. R. Coltman, G. C. Gerloff, and W. H. Gabelman, "A sand culture system for simulating plant responses to phosphorus in soil," Journal of the American Society for Horticultural Science, vol. 107, pp. 938-942, 1982.

[10] G. C. Elliott, "Evaluation of sand-alumina-P media for studies of P nutrition," Journal of Plant Nutrition, vol. 12, no. 3, pp. 265278, 1989.

[11] J. Lynch, E. Epstein, A. Lauchli, and G. I. Weigt, "An automated greenhouse sand culture system suitable for studies of $\mathrm{P}$ nutrition," Plant, Cell \& Environment, vol. 13, no. 6, pp. 547-554, 1990.

[12] Y.-L. P. Lin, E. J. Holcomb, and J. P. Lynch, "Marigold growth and phosphorus leaching in a soilless medium amended with phosphorus-charged alumina," HortScience, vol. 31, no. 1, pp. 94-98, 1996.

[13] K. A. Williams, Increasing phosphate and potassium retention of soilless container media through the use of clay, aluminum, and zeolite amendments [Ph.D. thesis], North Carolina State University, Raleigh, NC, USA, 1995.

[14] M. B. McBride, "Surface chemistry of soil minerals," in Minerals in Soil Environments, J. B. Dixon and S. B. Weed, Eds., pp. 3588, Soil Science Society of America, Madison, Wis, USA, 2nd edition, 1989.

[15] G. E. Brown Jr. and N. C. Strurchio, "An overview of synchrotron radiation applications to low temperature geochemistry and environmental science," Reviews in Mineralogy and Geochemistry, vol. 49, no. 1, pp. 1-115, 2002.

[16] Y.-M. Oh, D. L. Hesterberg, and P. V. Nelson, "Comparison of phosphate adsorption on clay minerals for soilless root media," Communications in Soil Science and Plant Analysis, vol. 30, no. 5-6, pp. 747-756, 1999.

[17] Y.-M. Oh, Development of a pre-plant source of phosphorus for soilless root media [Ph.D. thesis], North Carolina State University, Raleigh, NC, USA, 2000.

[18] R. J. Haynes and R. S. Swift, "Effects of air-drying on the adsorption and desorption of phosphate and levels of extractable phosphate in a group of acid soils, New Zealand," Geoderma, vol. 35, no. 2, pp. 145-157, 1985.

[19] G. W. Thomas, "Soil pH and soil acidity," in Methods of Soil Analysis Part 3, D. L. Sparks, Ed., pp. 475-490, American Society of Agronomy and Soil Science Society of America, Madison, Wis, USA, 1996.

[20] D. W. Nelson and L. E. Sommers, "Total carbon, organic carbon, and organic matter," in Methods of Soil Analysis Part 3, D. L. Sparks, Ed., pp. 961-1010, American Society of Agronomy and Soil Science Society of America, Madison, Wis, USA, 1996.

[21] M. L. Jackson, C. H. Lim, and L. W. Zelazny, "Oxides, hydroxides, and aluminosilicates," in Methods of Soil Analysis Part 1, A. Klute, Ed., pp. 101-150, American Society of Agronomy and Soil Science Society of America, Madison, Wis, USA, 2nd edition, 1986.

[22] R. A. Dahlgren, "Quantification of allophane and imogolite," in Quantitative Methods in Soil Mineralogy, J. E. Amonette and J. W. Stucici, Eds., pp. 430-451, Soil Science Society of America, Madison, Wis, USA, 1994. 
[23] S. Kuo, "Phosphorus," in Methods of Soil Analysis Part 3, D. L. Sparks, Ed., pp. 869-919, American Society of Agronomy and Soil Science Society of America, Madison, Wis, USA, 1996.

[24] G. Sposito, The Chemistry of Soils, Oxford University Press, New York, NY, USA, 1989.

[25] J. Murphy and J. P. Riley, "A modified single solution method for the determination of phosphate in natural waters," Analytica Chimica Acta, vol. 27, pp. 31-36, 1962.

[26] P. V. Nelson, C.-Y. Song, J. Huang, C. E. Niedziela Jr., and W. H. Swallow, "Relative effects of fertilizer nitrogen form and phosphate level on control of bedding plant seedling growth," HortScience, vol. 47, no. 2, pp. 249-253, 2012.

[27] J. B. Jones Jr., Tomato Plant Culture, CRC Press, Boca Raton, Fla, USA, 1999. 


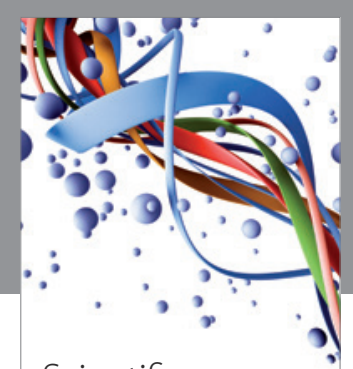

Scientifica
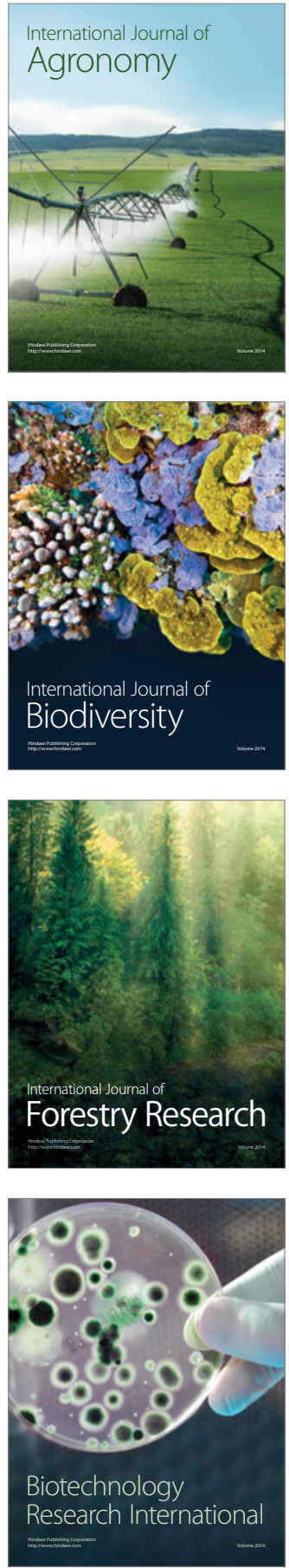
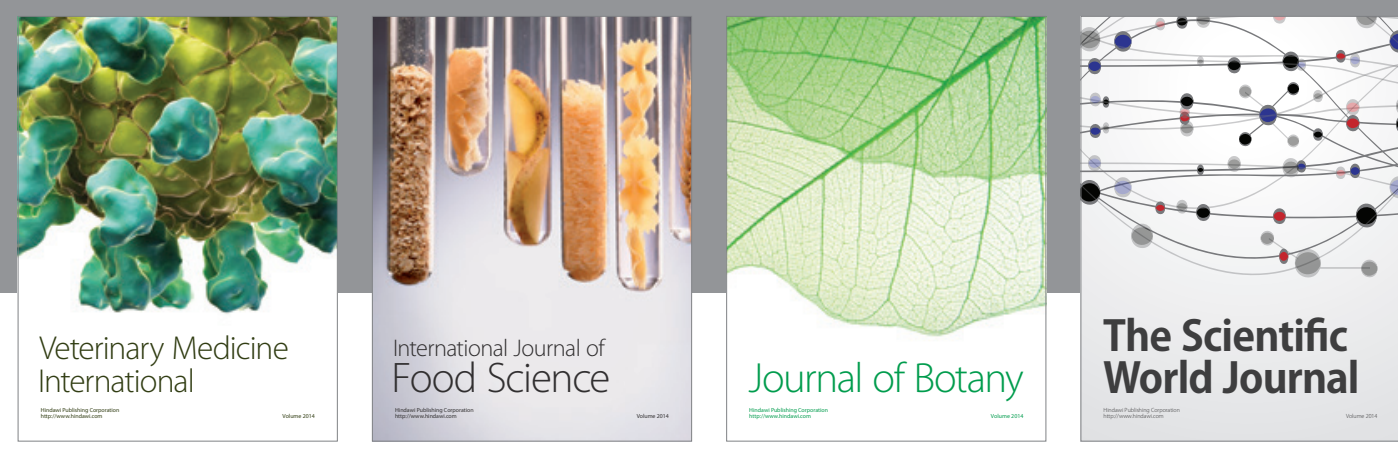

The Scientific

\section{World Journal}

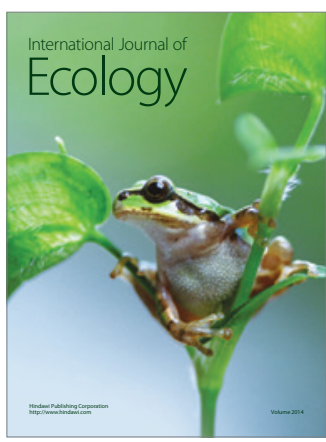

\section{Hindawi}

Submit your manuscripts at

http://www.hindawi.com
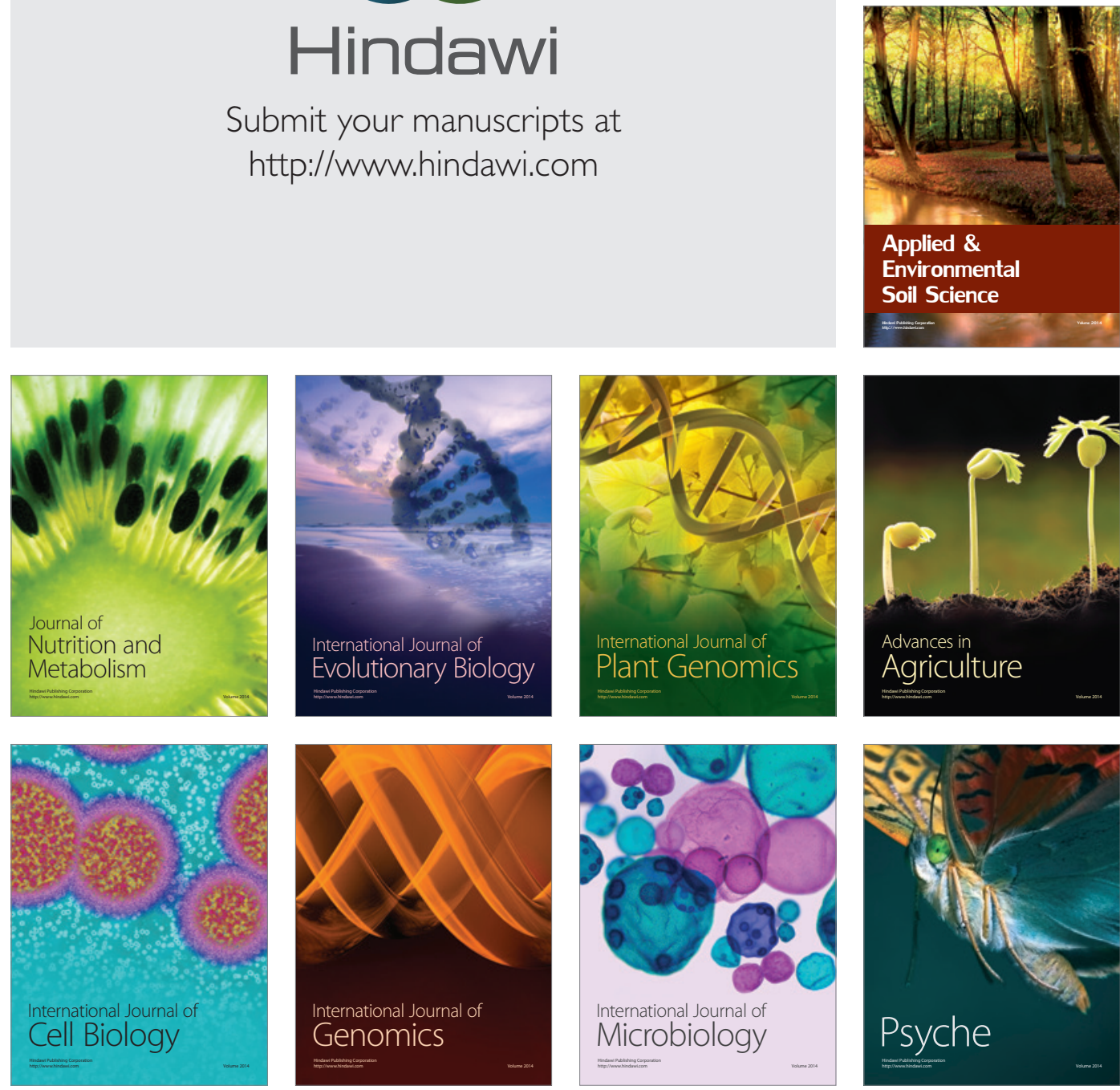
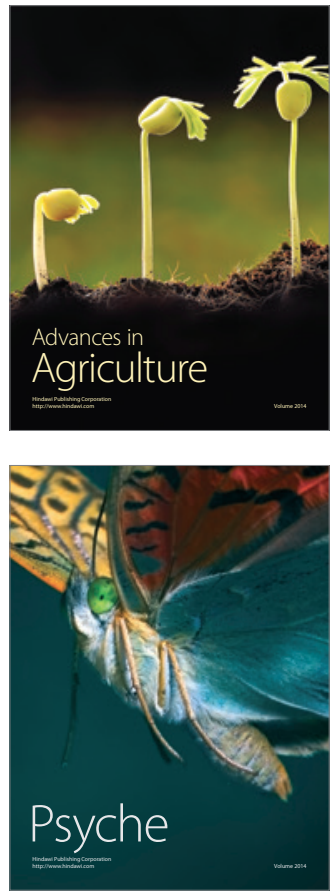